가톨릭대학교 의과대학 내과학교실

김 관 형

\title{
Airway Remodeling
}

Kwan Hyoung Kim, M.D.

Department of Internal Medicine The Catholic University of Korea College of Medicine

\section{1. 서 론}

1859년에 Henry Hide Salter가 최초로 천식을 가 역적인 기도 폐쇄질환으로 기술한 뒤, 1960년에 기도 과민성이 추가되었고, 1997년에 미국의 National Heart, Lung and Blood Institute에서 " 여러 가지 세 포 특히 비만세포와 호산구, $\mathrm{T}$ 임파구가 중요한 역할 을 하는 기도의 만성 염증성 질환이고 이 질환에 감 수성이 있는 사람에서 특히 야간 혹은 아침에 천명과 호흡곤란, 흥부 압박감, 통증이 반복적으로 나타난다. 이 증상의 일부는 자연적 혹은 치료에 의해서 호전되 는 가역적이며 다양하고 광범위한 기도제한과 연관 이 있고 다양한 자극에 대한 반응이 증가되는 것과 염증은 관련되어 있다”라고 정의 하였다 그 이후 지 난 30년 동안 이 복합적인 질환의 정의는 점점 확장 되어 왔다.

1922년에 Huber와 Koessler등이 천식으로 사망한 환자의 기도 벽과 평활근의 단면적이 다른 원인으로 사망한 환자보다 현저하게 두꺼워져 있는 것을 보고 한 것이 기도 개형에 관한 최초의 보고이며 그 이후 정상인에 비하여 치명적인 천식의 경우 기도 평활근 의 양이 50-200\% 치명적이 아닌 경우에는 25-150\% 정도 증가하는 것으로 보고 되었다. 대부분의 최근의 연구에서 소아에서도 유사한 변화가 보고되었다.

Address for correspondence: Kwan Hyoung Kim, M.D. Department of Internal Medicine, Uijonbu ST Mary's hospital, 65-1 Kumoh-dong, Uihongbu city, Kyunggido, Republic of Korea

Phone: 82-31-820-3661 Fax: 82-31-847-2719

E-mail: kwan-kim@catholic.ac.kr

\section{2. 기도 개형의 정의}

최근, 개형은 상피가 두꺼워지고 화생이 일어나고 상피하의 세포와 기질층이 두꺼워지는 것을 의미한 다. 넓은 의미는 회복이 신속하지 않는 해부학적인 변 화를 포함하며 근섬유모세포, 분비선, 맥관, 평활근, 신경, 세포외기질 등의 구조나 기존세포의 변화를 포 함하지만, 부종이나 염증세포 침윤 등의 급격한 변화 는 배제한다.

\section{3. 발생기전}

\section{1 기도 염증과 개형}

기도 염증이 천식의 핵심적 역할을 하지만 기도 염 증만으로는 만성적이고 재발하는 이 질환의 특징을 설명하기 어렵다. 오랫동안 호산구는 천식의 병인에 중심적 역할을 하는 것으로 인식되어 왔다. 그러나 항 $\mathrm{IL}-5$ 치료시 혈중(약 90\%), 객담(60-80\%), 조직내 (55\%)의 호산구를 감소시켰지만 임상적인 효과는 없 어서 기도 호산구의 증가나 아토피가 천식과 밀접한 관련이 있지만 천식 발현의 중요한 필수조건은 아닌 것으로 보인다. 또한 유전적인 연구에서 아토피와 기 도 과민성은 서로 다른 유전양상을 나타내므로 국소 적으로 작용하는 요소가 천식으로 발전시키는 데 중 요한 역할을 한다는 점을 시사하고 공해, 음식의 종 류, 호흡기 바이러스 감염등도 기도에서 oxidant stress를 증가 시켜서 천식발생의 중요한 위험 요소 로 작용한다.

염증세포와 기존의 상피세포간에 복잡한 상호작용 으로 기도 염증 반응을 협연하며 비만세포, 기도 상피 
세포, $\mathrm{CD} 4$ 임파구가 이 염증반응의 연출자로 제안되 었다. 적당한 감수성 유전자를 소유한 사람이 생애 초 기에 특정한 환경에 노출되면 특징적인 임파구성 기 도염증이 발생하고, 결국은 천식으로 발전한다는 이 론이 제시 되었다. 자궁내에서 어머니에 의한 태아 프 로그램과 유아기에 감염이 없는 것이 짝을 이루어 신 생아기의 naïve T 세포가 Th2 아형으로 분화하도록 생물학적인 환경이 만들어진다. Th2 싸이토카인은 전형적인 천식의 양상을 나타내는 기도의 구조적인 변화를 촉진한다. 이러한 방식으로 시작되는 만성적 인 기도염증은 바이러스 혹은 알레르겐에 의해서 유 발된 급성 염증으로 더 악화된다. 그래서 염증고리가 돌아가고 기도 개형이나 비정상적인 기도반응을 일 으킨다.

천식의 염증에서는 $\mathrm{IL}-4, \mathrm{IL}-5$ 그리고 $\mathrm{IL}-13$ 등 많 은 종류의 Th2-type 매개체와 호산구와 더불어 proteoglycan, tenascin, lumican등이 그물망에서 증 가되고 이들은 개형에서 중요한 역할을 한다. 인간형 항 $\mathrm{IL}-5$ 단일클론항체(humanized anti IL-5 monoclonal antibody; mepolizumab)는 호산구 뿐만 아니 라 기도의 tenascin, lumican, 그리고 procollagen III 을 감소시키고 기도폐포 세척액내의 TGF- $\beta 1$ 을 감소 시킨다. 기도 중등도 혹은 중증 천식환자에서 $\mathrm{TGF}-$ $\beta, \mathrm{IL}-11, \mathrm{IL}-17$ 그리고 collagen type I, III의 발현이 증가하는데, 스테로이드 치료는 $\mathrm{IL}-11$ 그리고 $\mathrm{IL}-17$ 의 발현은 감소 시키지만 TGF- $\beta$, collagen I 혹은 III 은 감소 시키지 못하여서, 기도 개형이 스테로이드치 료에 반응하지 않는 이유를 설명할 수 있다. 중등도에 서 중증의 천식환자에서는 장기간의 치료로 기도 과 민성은 호전시키지만 비정상 상태로 남아 있는 경우 가 많으며, 스테로이드 치료에 잘 반응하지 않는 구조 적인 변화는 아마도 기도 개형으로 때문인 것으로 생 각한다.

소아에서 흡입용 스테로이드는 초기에는 잘 반응 하다가 3 년이 지나면 반응이 감소하게 된다. 이것은 기도 개형이 스테로이드에 잘 반응하지 않은 것으로 설명한다. 최근에는 소아에서 조직검사상 호산구의 침착보다는 그물망에 야교질의 침착과 섬유모세포의 증식을 천식의 진단적 특징으로 강조하게 되었다.
상피 술잔세포의 증식, 화생(metaplasia), 그물판 (lamina reticularis)의 비후나 아교질(collagen)의 침 착, 기도 평활근의 증식, 그리고 기도 혈관과 신경의 증식은 진행중인 천식에서 일관되게 발견되는 소견 이며 기도의 점막과 외막의 비대는 기도 과민성에 기 여한다. 기도 개형은 기도 염증이 오래 지속되어 발생 하는 것으로 여겨 왔으나 증상이 발병하기 4년 전부 터 조직의 재 개편이 일어나는 것으로 보고되고 있어 서 이 과정은 조기에부터 발생하며 염증과 별도로 진 행되거나 지속적인 염증이 있는 것을 시사한다.

\section{2. 천식의 향상피세포-중간엽 단위(epithelial mesenchymal trophic unit; EMTU)}

천식에는 유전적 소인이 있다고는 하지만 과거 30 년 동안 유병률이 예상보다 많이 증가되고 만연하여, 유전적 소인의 변화가 증가의 원인이라고 하기는 어 려우며 역학적 조사에 의하면 천식을 유도하고 악화 시키는 많은 요소들이 유병률 증가의 원인임을 밝히 고 있다.

기도 상피세포는 주변환경에 대한 장벽으로서 유 전자-환경의 관계를 조절하는 핵심적인 역할을 하는 데, 천식환자의 상피세포는 구조적 그리고 기능적으 로 비정상적이라는 점이 조금씩 밝혀지고 있다. 천식 환자의 상피 세포는 반응기 산소에 대한 세포자멸사 감수성이 높고 오존이나 nitrogen dioxide에 노출된 후에 기도 상피세포의 투과성이 증가 하고 디젤배기 입자에 자극을 받으면 천식이 아닌 사람보다 더 많은 $\mathrm{IL}-8$ 과 GM-CSF를 유리 한다. 발생기 산소나 입자는 낮은 역치에서 상피세포를 손상시키고 상피세포의 활성화를 촉진시키는 작용을 한다. 이와 같은 감수성 의 증가를 반영하는 것으로 천식에서 상피세포의 탈 락은 다른 질환에서 발견되지 않는 특징이다. 만성폐 쇄성 폐질환에서는 편평 상피세포 화생이 일어나기 때문에 상피가 다층으로 된다. 반면에 천식에서는 세 포자멸사에 의해서 상피세포 탈락이 일어나고 손상 된 부위에 EGFR의 발현이 증가되지만 만성 폐쇄성 폐질환과 달리 상피 세포에서 $\mathrm{EGFR}$ 의 증가에 의한 세포증식은 일어나지 않는다. 이것은 cyclin/cyclin- 
dependent kinase inhibitor P21 ${ }^{\text {waf }}$ 의 발현이 높기 때 문이다. 천식에서 항 증식성인 TGF- $\beta 1, \beta 2$ 이 증가되 어서 억제적인 G1 cyclin이 유도되고, P21 ${ }^{\mathrm{waf}}$ 은 상피 세포의 복구를 늦게 하여 상피세포의 전염증성 표현 형이 유지 된다.

상피세포는 전염증성 매개체의 분비 뿐만 아니라 손상된 상피세포에서 섬유모세포의 증식을 촉진하는 $\mathrm{TGF}-32$ 와 fibroblast growth factor, insulin growth factor, platelet-derived growth factor, endothelin 1, 그리고 TGF- $\beta$ superfamily의 다른 구성원등 섬유모 세포 증식성 혹은 profibrogenic growth factor를 분 비한다. 이들 중 $\mathrm{TGF}-\beta$ 는 섬유모세포를 근섬유모세 포로 분화를 촉진 시킨다. 또한 근섬유모세포는 평활 근이나 혈관내피세포에 분열촉진제로 작용하는 간질 성 아교질, endothelin 1 이나 $\mathrm{VGEF}$ 같은 성장요소를 분비한다.

상피에서 $\mathrm{TGF}-\beta$ 를 유리하고 기존의 섬유모세포 와 근섬유모세포에 작용함으로써 시작되는 기도 개 형의 신호는 복구되는 상피세포에서 점막하의 깊숙 한 층으로 전파되고 증폭되어간다. Holgate등은 이와 같은 상피세포와 중엽간의 의사소통은 태생기 발생 의 기도형성의 잔상으로서 생후까지 남아 있거나 혹 은 천식에서 다시 활성화되어 기도의 개형을 유발하 는 향 상피-중엽 단위 개념(EMTU)을 제안하였다.
이 모델에 의하면 기도 염증과 개형은 손상에 대한 감수성의 증가와 상처의 치유장애 혹은 두 가지에 의 해서 일어난다.

\subsection{Th2 염증과 EMTU}

Th2 형 기도 염증반응은 아토피의 여부에 관계 없 이 천식의 특징적인 소견이다. $\mathrm{IL}-13$ 은 기도 상피에 서 TGF- 32 의 분비를 증가 시키므로써 상피세포를 경유하여 상피하 조직의 개형을 시작 하는 것으로 보 인다. IL-4나 IL-13은 상피 세포에서 신호 유도 촉진 자(transducer) 혹은 transcription 6 phosphorylation 의 활성인자를 증가시키고 $\mathrm{GM}-\mathrm{CSF}$ 나 $\mathrm{IL}-8$ 의 생산 을 증가 시킨다. 이 싸이토카인등은 점액(mucin) 유 전자 발현에 연관된 TGF- $a$ 를 분비하고 섬유모세포 로부터 eotaxin의 분비를 증가 시킨다. EMTU의 세 포와 $\mathrm{IL}-4$ 나 $\mathrm{IL}-13$ 의 상호작용은 만성 염증과 기도 개형을 증가 시키며 상피세포의 손상과 Th2 싸이토 카인으로 EMTU의 기능 장애를 일으키고 근섬유모 세포의 활성화와 만성 천식의 특징인 염증과 기도 개 형을 유도한다. 이점은 과거의 천식의 병인이 순서적 으로 일어나는 개념에서 Th2염증과 구조적인 변화가 나란히 일어난다는 점이 다르다. 천식의 발현은 아토 피와 국소적인 감수성 유전자의 상호작용에 의존하

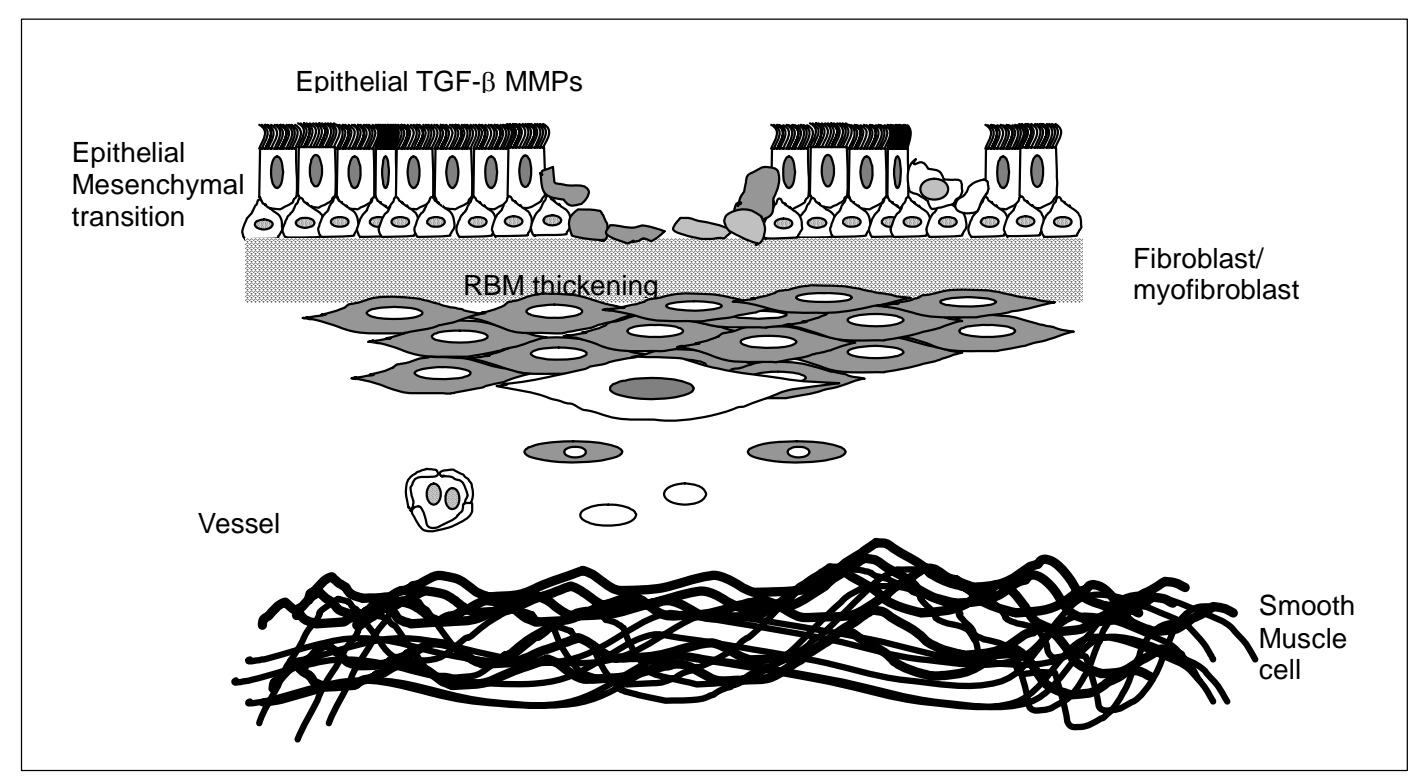


며 반면에 아토피의 유전은 천식 없이도 일어난다.

폐의 발달 중에 상피와 중엽의 성장은 $\mathrm{EGF}$ 와 $\mathrm{TGF}-\beta$ 신호의 평형에 의해서 조절된다. 그래서 감 수성 있는 환자에서는 환경적인 요소와 EMTU가 상 호작용하여 기도의 구조적인 변화가 시작되고 소아 기에도 폐 기능이 감소하고 스테로이드에 반응하지 않는 경우를 초래할 수 있다.

\section{4. 기도 섬유모세포와 평활근의 표현형의 유연성}

근섬유모세포는 수용성 매개체를 유리하여 기도 상피세포로부터 점막하조직에 신호를 전달하고 증폭 함으로써 EMTU에서 중심적인 역할을 한다. 천식환 자에서는 알레르겐 유발후 그물판에 근섬유모세포양 세포가 증가하는데 이것은 상피 세포가 알레르겐에 노출후 근섬유모세포가 이주하거나 혹은 평활근이 근육 다발로부터 화학주성물질에 의해서 그물판으로 이동할 것으로 추측된다. 근섬유모세포의 표현형은 섬유모세포와 평활근의 중간이며 표현형의 유연성 때문에 직접적으로 평활근 덩어리의 증가에 기여 할 것이다. 섬유모세포에는 알려진 특이 표식자는 없지 만 근섬유모세포는 a 평활근 actin 미세섬유(aSMA) 혹은 비근육성 액틴과 마오신을 함유하는 스트레스 섬유를 표현한다. 그러므로 protomyofibroblast(세포 질성 액틴을 포함하는 스트레스섬유의 발현)와 분화 된 근섬유모세포(aSMA를 포함하는 스트레스섬유를 발현)의 두 가지로 나뉜다. 평활근은 아교질 유전자 발현등 근섬유모세포의 형태학적 기능적인 특징을 획득하며 근섬유모세포는 어떤 상황에서는 $\mathrm{aSMA}$, heavy-chain myosin, desmin을 발현하기 때문에 근 섬유모세포 표현형은 주위 미세환경에 따라서 섬유 모세포로 혹은 평활근 표현형으로 변화하는 유연성 을 나타내는 것으로 생각된다. $\mathrm{TGF}-\beta$ 는 섬유모세포 -근섬유모세포 형질전환을 시키는 가장 강력한 매개 체이다. 그리고 $\mathrm{TGF}-\beta$ 는 $\mathrm{IL}-1 \beta$ 유도성 세포 자멸사 를 차단함으로써 근섬유모세포의 수명을 연장하는 것으로 알려져 있다. $\mathrm{IL}-4$ 과 비만세포의 히스타민과 tryptase는 섬유모세포에서 aSMA의 발현을 상향 조 절하며 기계적인 영향 또한 근섬유모세포의 표현형
의 조절에 중요한 작용을 하는 것으로 보인다. 지속적 인 인장은 평활근 단백질의 발현을 유도하고 평활근 의 근육발생을 가속화시킨다. 그래서 기도의 지속적 인 수축과 이완은 섬유모세포의 표현형에 영향을 주 며 이것은 특히 기도과민반응과 천식의 관점에서 중 요하다. 세포외 기질은 중엽세포의 생존에 중요하고 평활근의 표현형에 영향을 미친다. 아교질 I, 그리고 $\mathrm{IV}$, fibronectin, vitronectin laminin은 시험관내의 평 할근의 수축성 표현형을 유지한다.

\section{5 평활근 뭉치의 증가}

\section{1) 근세포의 증식}

기도 평활근 분열 촉진물질들은 여러가지 다른 수 용체를 통하여 작용한다. 성장인자들은 tyrosine kinase(RTK)활성능을 가진 수용체를 활성화 시켜서 평활근세포의 분열을 촉진시키고 염증세포로부터 유 리된 수축성 항진제는 $\mathrm{G}$-protein coupled 수용체 $(\mathrm{GPCRs})$ 를 활성화 시켜서 작용하며 RTK와 GPCRs 이 상호작용하여 평활근 세포분열을 촉진하는 데 상 승작용을 한다. Phosphatidylinositol 3-kinase (PI3K) 과 extracellular signal - regulated kinase (ERK)의 활성화가 RTK, GPCR 혹은 싸이토카인 자극에 의한 기도 평활근의 성장에서 중요한 신호전달 경로인 것 같다. $\mathrm{PI} 3 \mathrm{~K}$ 는 막의 phsophoinositide를 인산화하고

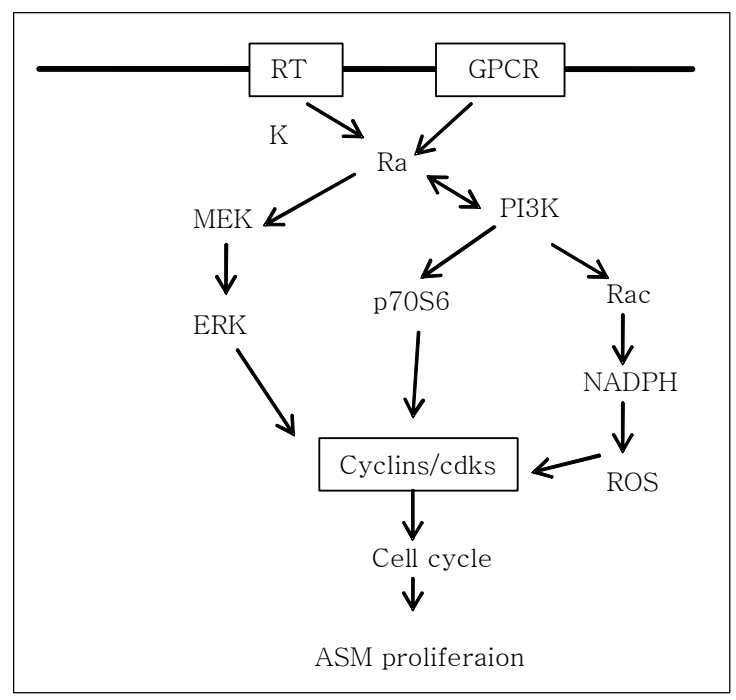


이것은 2 차 매개인자로 작용하고 세포 주기 단백질 발현의 효과 분자를 활성화 하여 세포주기를 조절한 다.

D-type $\operatorname{cyclin}(\mathrm{D} 1, \mathrm{D} 2, \mathrm{D} 3)$ 이 척추동물에서 $\mathrm{G} 1$ progression의 핵심적인 조절자이다. 스테로이드는 평활근에서 분열 촉진자에 의한 cyclin D1의 증가를 억제한다. 스테로이드가 수용체에 결합하면 전사인자 $\mathrm{C} / \mathrm{EBPa}$ 를 활성화하고 결과적으로 $\mathrm{cyclin}$ 의존성 kinase 억제제 $\mathrm{p} 21 \mathrm{WAF} / \mathrm{Cip} 1$ 의 발현을 증가 시켜서 기도 평활근에 대한 증식을 억제한다. 천식환자의 기 도 평활근에는 $\mathrm{C} / \mathrm{EBPa}$ 의 발현이 없어서 스테로이드 를 사용하여도 기도 평활근의 증식에 대한 억제작용 이 약하다. 반응기 산소는 기도 평활근의 기능에 영향 을 미칠 수 있으며 반응기 산소는 분열 촉진자에 의 한 기도 평활근의 증식을 조절할 수 있다. 또한 STAT3는 Platelet- derived growth factor(PD GF) 에 의한 기도 평활근의 증식에 중요한 역할을 하는 것으로 보인다.

\section{2) 근섬유의 비대}

천식에서 기도 평활근 뭉치 증가는 근섬유의 크기 증가 혹은 비대에 의해서 이루어진다. $\mathrm{IL}-1 \beta, \mathrm{IL}-6$, $\mathrm{TGF}-\beta$, angiotensin II, 그리고 cardiotrophin I 같은 매개체는 시험관내에서 세포의 비대를 초래한다. 세 포 크기의 증가는 기관지 확장제 투여후의 $\mathrm{FEV}_{1}$ 과
역상관계가 있다. Woodruff등은 중등도에서 중증환 자의 조직검사에서 기도 평활근의 증식은 있었지만 비대의 증거는 없었다고 하여 이 분야에 대한 좀 더 연구가 필요하다.

\section{3) 평활근의 이주}

동맥경화에서 발생하는 혈관 내피세포의 이주와 유사하게 만성 천식환자에서도 기도 평활근의 이주 가 기도 개형을 촉진하고 기도 평활근의 화학 주성의 경사에 따라 이동한다. 만성 염증에서는 변화된 세포 외 기질이나 다양한 싸이토카인과 성장인자에 노출 되어 평활근의 이주가 촉진된다. 구조적으로 근섬유 모세포는 aSMA를 발현하고 세포외기질을 분비할 수 있는 능력이 있으며 표현형은 섬유모세포와 평활근 세포의 중간형이다. 또한 근섬유모세포는 chemokine 을 분비하고 호산구의 수명을 연장 시킨다. 조직내 섬 유모세포보다는 기관지폐포세척액내의 섬유모세포 가 이주 능력이 더 증가되어 있고 기도 평활근은 PDGF, TGF- $\beta$, basic fibroblast growth factor, 그리 고 $\mathrm{IL}-1 \beta$ 등에 화학 주성이 증가 되어 있다. Cysteinyl leukotriene 단독으로 화학운동성을 증가 시키지만 $\mathrm{PDGF}$ 와 합동하여 화학주성을 증가시킨다. 혈관 평활근에 강력한 이주능력이 있는 $\mathrm{VGEF}$ 는 기 도 평활근에 대한 작용은 없으나 세포외 기질은 기도 평활근의 이주에 영향을 미친다. 기도 평활근은 coll-

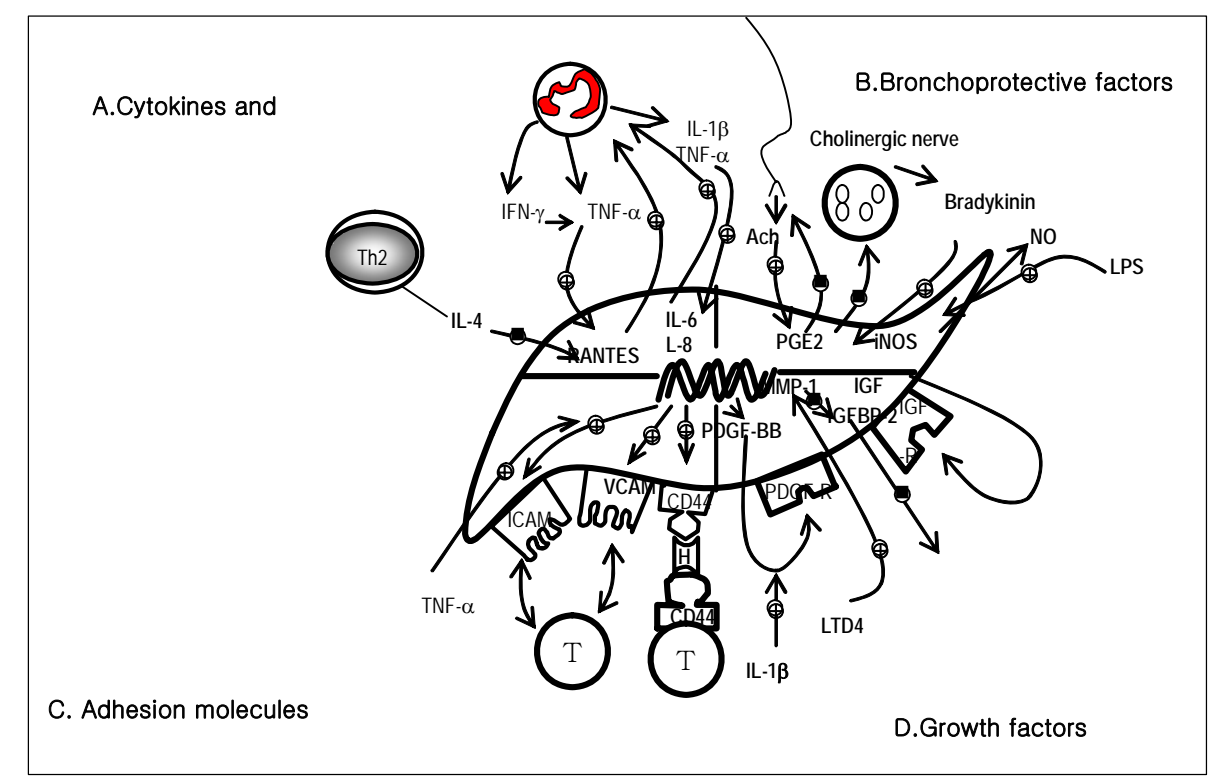


agen I, elastin 혹은 laminin보다 collagen III,V 그리 고 fibronectin에 반응하여 이주가 증가된다. 스테로 이드는 시험관내에서 기도 평활근의 이주를 억제한 다. $\mathrm{PDE} 4$ 억제제 혹은 $\beta 2$ 항진제는 약간 중등도의 효과를 나타내지만 약간의 스테로이드를 같이 사용 하면 효과는 증대된다.

\section{6. 염증세포의 침윤}

기도 평활근은 $\mathrm{TNF}-\mathrm{a}$ 그리고 $\mathrm{IL}-1 \beta$ 에 반응하여 RANTES, eotaxin, IL-8, monocyte chemotactic protein (MCP) 1, MCP-2, MCP-3, thymus and activation-regulated chemokine, 그리고 GM-CSF를 분비한다. 기도 평활근은 $\mathrm{GM}-\mathrm{CSF}$ 와 $\mathrm{IL}-5$ 의 분비로 호산구의 수명을 연장하거나 동원을 촉진한다. 또한 Stem cell factor를 분비하여 기도 평활근층에 비만세 포의 동원과 유지를 돕고 염증세포를 기도내로 동원 하는 Chemokine을 분비하고 세포유착분자를 발현하 여 백혈구의 저류와 활성을 돕는다. 활성화된 $\mathrm{T}$ 세포 와 기도 평활근의 동시 배양은 평활근의 $\mathrm{DNA}$ 합성을 현저하게 유도하며 T세포의 부착은 $\mathrm{IL}-5$ 나 $\mathrm{IL}-1 \beta$ 의 자가분비 때문에 기도 평활근의 수축력을 변화시킨 다. 기도 평활근이 활성화된 $\mathrm{T}$ 세포와 같이 배양되면 LTD4나 serotonin에 반응하여 칼슘의 mobilization이 증가된다. 반면에 비만세포에 의한 lipid 매개체나 효 소의 유리는 기도과민반응을 증진시키고 기도 기도 평활근의 증식을 억제하거나(chymase) 혹은 증가시 킨다(tryptase). 이들은 기도 평활근과 백혈구의 상호 작용으로 국소적인 환경을 바꾸고 기도 평활근의 활 성과 성장, 백혈구의 활성과 수명에 영향을 미친다.

\section{7. 상피 세포의 역할}

$50 \%$ 의 천식 환자는 아토피와 연관되어 있으며 천 식의 빈도가 증가하는 것은 알레르겐에 대한 노출과 더불어 서구화된 생활 양식 때문이다. 대부분에서 천 식에 대한 감수성은 태아 때와 생후 3-5년 내에 대개 결정되는 것으로 보인다. 이 중요한 시기의 불안정 상태는 생애 초기에 기도가 반복적으로 바이러스에
잘 감염되도록 하고 흡연등 환경 오염에 감수성이 높 게 하고 공기 알레르겐에 대하여 하부기도가 쉽게 감 작되도록 한다. 기도 과반응은 염증반응과는 별개의 것으로 광범위의 기도 손상과 기도의 세포외기질 단 백질의 축적, 술잔세포의 metaplasia, 기도 평활근의 비대 신경과 혈관수의 증가등 개형의 다른 특징을 나 타내는 구조적인 변화가 반영한다. 이것들이 염증의 결과로 생기는 것인지 혹은 염증과 별개로 발생하는 지는 모르지만 기도의 구조적인 요소등이 변하여 싸 이토카인과 성장요소등을 분비하고 염증반응을 유지 하는 데 기여한다.

\section{상피의 손상과 스트레스}

천식의 중요한 특징인 상피세포의 탈락은 객담내 상피세포 덩어리(Creolar body)나 기관지 내시경으로 검사한 생검상 기도 상피세포가 단락되는 것으로 알 수 있다. 손상되거나 복구되는 세포는 증가하지만 육 안적으로는 변화가 없다. 손상되지 않은 곳의 미세구 조상 세포간의 정상적인 연결상태를 유지하기 때문 에 천식의 상피는 손상에 대하여 감수성이 높아졌거 나 반응이 변경된 것으로 설명한다. 피부에서는 여러 층의 keratinized 세포로서 기계적인 결성을 이루는 피부와 대조적으로 기도 상피세포는 일차적으로 기 저세포와 그 위에 원주세포로 구성되어 있다. 기저세 포는 원주세포에 비하여 기저판에 더 단단하게 부착 되어 있고 상피세포가 손상되면 주로 원주상피세포 를 잃게 된다. 상피세포의 점액생산과 섬모운동에 의 해서 흡입된 인자가 제기되는데 분화된 상피 세포가 없는 경우에는 이 청소율은 떨어진다. 기도 상피 전체 층의 손상 시에는 복구는 일시적인 fibrin-fibrinogen 기질판을 만든 후에 상피세포의 탈분화 그리고 상피 세포가 기저막의 벗겨진 부분으로 이동하여 포장하 는 방법으로 시작된다. 일단 상피세포가 기저막을 씨 우면 세포의 증식과 분화로 정상적인 상피의 구조를 다시 회복하게 된다. 기관지 천식의 상피에는 heat shock protein의 발현이 증가되어 있고 $\mathrm{NF}-\mathrm{kB}$, activator protein(예 activator protein-1), signal transduction and activator of transcription-1 (STAT-1)의 발현이 증가되고 EGFR의 발현이 증가 
되어 있다.

\section{전염증 매개체 제공처로서의 상피}

천식에서 구조적 개형이 일어나는 주요장소는 lamina propria 와 lamina muscularis mucosa이며 기 저막하 세포외기질의 비후와 평활근의 비대가 특징 이다. 알레르겐이나 protease의 직접적인 효소작용과 oxidant, 바이러스나 세균, 물리적인 뒤틀림 등을 포 함한 내인성 혹은 외인성 자극은 시험관내에서 상피 세포를 활성화 시킨다. 많은 자극들은 특이적 수용체 매개성 과정(예, protease-activated receptors(PARs) 혹은 $\mathrm{NF}-\mathrm{kB}$ 나 activator protein-1의 활성화와 함께 스트레스 반응을 유도하고 많은 싸이토카인과 성장 인자를 생산하고 분비한다. 천식에서 상피 세포는 스 트레스에 반응하여 autacoid mediators, chemokines, 성장 인자를 생산한다.

\section{상피 복구의 제 1 조절자인 $\mathrm{EFGR}$}

부착분자와 성장인자등으로 세포외 신호를 받아서 세포내 생화학적인 반응망에 의해서 발현되는 유전 자의 활성능에 의해서 조직 복구가 조절된다. 성장인 자 수용체중 $\mathrm{EGFR}$ 은 기도 상피세포기능의 제 1 조절 자이다. $\mathrm{IFN}-r$ 에의한 $\mathrm{PGG} / \mathrm{H}$ synthase-2의 발현은 $\mathrm{IFN}-r$ 에의한 EGFR ligand 의 상향조절후 $\mathrm{EFGR}$ 의 자가분비 활성화를 통하여 일어난다. ligand와 무관 하게 환경적인 스트레스에의한 기전으로 ET- 1 , bradykinin, G protein-coupled 7-transmembrane receptor 혹은 반응성 산소에 의해서 혹은 싸이토카인 수용체등으로 EGFR의 전사가 촉진될 수도 있다.

\section{기도상피 세포의 복구와 천식에서의 복구의 장애}

정상인의 상피세포에서는 손상된 부분에만 $\mathrm{EGFR}$ 이 증가되어 있지만 천식에서는 손상된 곳과 형태학 적으로는 정상으로 보이는 곳까지 광범위하게 $\mathrm{EGFR}$ 이 발현되고 그 정도는 기저막하의 collagen 두께와 비례한다. Psoriasis나 악성종양에서는 EGFR의 과발 현은 $\mathrm{EGFR}$ 의 자가분비 고리에 의해서 상피세포의 증식과 동반되는데 천식에서는 적어도 기초상태에서 는 증식이 동반되지 않는다. 광범위하게 shedding이
되지만 proliferating cell nuclear antigen(PCNA)의 발현이 기저 세포에 편중된다. 상피세포에서 증식신 호의 억제로서 유력한 것은 $\mathrm{TGF}-\beta$ 이며 $\mathrm{EGF}$ 에 반대 작용하여 상피세포의 증식을 억제한다. TGF- $\beta$ 경로 와 $\mathrm{EGF}$ 경로는 Sma and $\mathrm{Mad}-$ related proteins (SMAD)에서 만나기 때문에 전체적인 증식성의 결정 은 분열촉진인자와 분열억제인자사이의 균형에 의해 서 조절된다. 천식에서 상피세포에 EGFR ligand의 발현 증가는 없으나 기관지폐포세척액에 $\mathrm{TGF}-\beta$ 는 증가되었다. 그래서 이와 같은 불균형으로 기도 상피 세포의 증식이 없다. EGFR 매개성 상피세포의 증식 에 대한 $\mathrm{TGF}-\beta$ 의 길항효과는 태생기 폐의 발생 때 분지형성에 나타나는 상호관계의 흔적이다. 스테로이 드 치료시 천식의 상피에 PCNA발현이 현저하게 증 가하지만 상피의 복구에는 영향이 없고 다만 염증성 손상을 억제함으로서 복구에 도움을 줄뿐이다.

\section{상피의 SBM collagen 침윤}

상피의 SBM collagen의 비후는 임상적으로 천식 을 나타내기전 이르면 4 년전부터 나타나고 5개월된 영아에서도 나타난다. 상피 SBM 부위의 lamina reticularis에 침착된 간질성 collagen은 천식의 특징 이며 다른 질환에는 나타나지 않는 특징이다. 일부 보 고에서 질환의 중등도에 비례하여 $\mathrm{SBM}$ 이 두껍다고 하였다. SBM의 비후는 비아토피성 천식, 내인성 천 식, 만성 폐쇄성 폐질환에 호산구 증다증이 겸비된 천 식에서 특징적으로 나타나지만 만성폐쇄성 폐질환 단독으로는 나타나지 않는다. 천식이 없는 과민성인 아토피성 환자에서는 $\mathrm{SBM}$ 의 두께는 천식과 비천식 환자의 중간 정도이다. 두께 증가보다 더 주요한 것은 밀도의 증가이다. lamina reticularis의 두께와 밀도의 증가는 기도 평활근이 수축할 때 상피의 주름을 증가 시켜서 과도하게 기도 내경을 좁게 한다.

The attenuated fibroblast sheath and the epithelial-mesenchymal trophic unit

상피하에 SBM collagen 층에 비례하여 $\mathrm{mAb}$ $\mathrm{PR} 2 \mathrm{D} 3$ 롤 염색되는 섬유모세포가 증가하는 데 이것 은 Evans등이 기술한 섬유모세포집(sheath)에 상응 


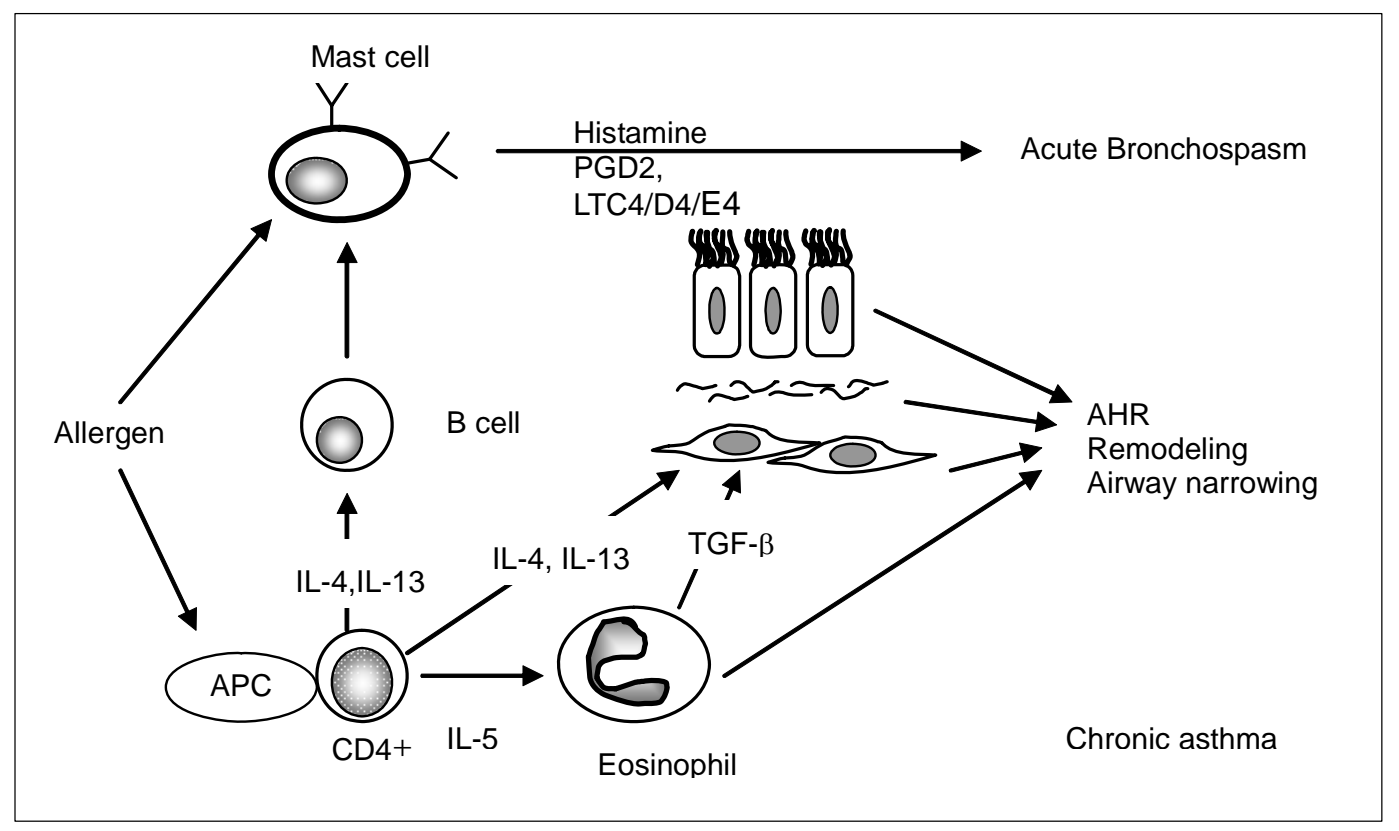

하는 것이며, 간(liver) 섬유화의 stellate세포나 장과 신장, 폐포, 활막(synovium), 육아종, 유방, 그리고 자 궁내막에 있는 juxtaparenchymal cell과 같은 것으로 서 그물망을 형성한다. 상피에 접해있는 얇아진 근섬 유모세포층은 외부나 내부의 자극에 반응할 수 있도 록 통합된 단위를 형성한다. 상피와 얇아진 섬유모세 포판 사이에는 수용성 매개체를 통한 양방향의 의사 소통과 neuropeptide의 분비로 주변의 기질과 상호작 용하고 대장의 pericryptical fibroblast에있는 틈새 이 음(gap junction)을 통해서 세포와 세포가 접촉하는 것과 유사하다. 또한 상피세포와 기저막 사이에는 독 특한 전달 통로가 있다. 이 통로는 염증성 혹은 면역 세포가 상피로 이주하는 것을 돕는다.

기관지분지(branch)형성 조절의 핵심은 세포외기 질이며 틈새(cleft)에 세포를 모으고 상피의 성장을 제한하고 반면에 주변의 제한 받지 않은 상피는 계속 성장하여 분지를 만든다. 이와 같은 분지 형성과 기질 개형의 복잡한 과정은 많은 성장인자에 의해서 협연 되며 이들 중 중요한 것은 EGF-like growth factor와 $\mathrm{TGF}-\beta_{\mathrm{s}}$ 등이다. $\mathrm{EGF}$ 는 상피세포의 증식과 matrix metalloproteinases(MM Ps)의 생산을 촉진하고 세포 외 기질을 분해한다. 반면에 $\mathrm{TGF}-\beta$ 는 세포외기질의 합성을 조장하고 $\mathrm{EGF}$ 유도성 증식과 $\mathrm{MMP}$ 합성을 억
제한다. 이러한 방법으로 틈새부분은 단백질 분해능 이 낮고(TIMP가 풍부하고) 반면에 분지 형성은 증식 과 신속한 기질의 분해를 특징으로 한다.

\section{천식에서 EMTU의 활성의 재개}

천식에서 간질성 collagen과 다른 기질성 단백질이 광범위하게 침윤한다는 점은 이 질환에서 $\mathrm{EMTU}$ 가 다시 활성화 됐다는 점을 의미한다. 두 구획간의 의사 소통 설정의 변화는 중간엽 용적의 변화를 초래한다. 이것은 천식의 기도에서 $\mathrm{TGF}-\beta$ 가 증가되어 있고 상 피 손상부위에서 상피의 증식이 저조하며 기질의 축 적이 가장 현저한 중증의 천식에서 $\mathrm{MMP} / \mathrm{TIP}$ 비가 감소하는 점과 일치한다. 기질의 생합성을 조절하는 요소들과 더불어 기도 $\mathrm{MMP}$ 의 활성능의 정도와 protease/antiprotease의 평형이 기질의 대사주기의 정도, 기질에 관련된 cytokine의 유용성, 태아에서 성 장하는 폐에서 발견되는 기질과 상피간의 유익한 신 호전달을 결정한다.

\section{Th2 cytokine와 EMTU의 상호관계}

술잔세포 화생, 점액의 과분비는 $\mathrm{IL}-4, \mathrm{IL}-13$ 혹은 EGFR ligand에 의해서 유도될 수 있다. 또한 IL-13 의 과발현은 기도 과민성과 관련이 있는 평활근의 증 
식과 상피하 섬유화에 영향을 주어서 IL-13는 천식의 표현형을 유지하는데 핵심적인 역할을 하는 것으로 보인다. $\mathrm{IL}^{-4}$ 와 $\mathrm{IL}-13$ 는 또한 상피의 유도성 nitric oxide synthase, eotaxin, IgA secretary component 의 발현에 관여하고 섬유모세포에서 $\mathrm{IL}-4$ 혹은 $\mathrm{IL}-13$ 은 RANTES, eostaxin, IL-6, MCP-1, ICAM-1, VCAM-1, $\beta 1$-integrin 발현을 촉진하고 $\mathrm{IL}-4$ 는 섬유 모세포로부터 근섬유모세포로의 분화를 촉진한다. $\mathrm{IL}-4$ 수용체의 다형성은 STAT6의 활성의 증가와 관 련이 있기 때문에 Th2 구성의 부적절한 조절은 상피, 그리고 중엽의 기능에 영향을 주고 기도의 구조적 그 리고 염증세포간의 공통연결을 제공하여 천식을 표 현하는데 협력 할 것이다.

\section{8. 상피하 섬유화}

세포외기질 단백질은 기도의 구조와 기능을 유지 하는데 핵심적이다. 기도 평활근세포는 세포외기질 구성물과 기질변경 효소를 생산하여 기도의 개형에 기여한다. 또한 반대로 세포외기질은 기도 평활근의 성장과 합성 기능에 영향을 미친다. 세포외기질의 구 성물은 아주 엄격하게 조절되고 기질의 침윤과 분해 의 동적인 과정에 관여한다. 염증상황에서는 이 평형 은 깨지고 기질의 양과 질적인 변화를 가져온다. 기도 평활근세포는 fibronectin, collagen, hyaluronan, laminin, 그리고 versican를 포함한 다양한 기질 단백 질을 분비한다. $\mathrm{TGF}-\beta$ 는 기도 평활근에서 분비되 지만 반대로 기도 평활근에서 hyaluronan 과 collagen의 분비를 유도한다. 또한 기도 평활근은 $\mathrm{VGEF}$ 를 분비하고 이것은 기도 평활근에서 fibronectin을 발현하게 한다. LTD4와 epidermal growth factor는 기도 평활근에서 versican과 fibronectin 의 발현을 증가 시킨다. 기도 평활근은 천식환자의 혈청 에 반응하여 세포외기질 단백질을 분비하기 때문에 기도 평활근이 세포외기질 침착의 세포적인 제공자 이며 기도 평활근이 아마도 자가 증식반응을 조절하 는 독특한 기전에 참여하는 것으로 생각된다. 천식에 서 증가된 기질의 침착은 중엽세포의 분비의 증가와 그리고 기질분해효소와 이 효소 억제제의 불균형 때
문이다.

\section{9. 기도 신생혈관증식 (neovascularization)}

신생 혈관 형성과 미세혈관의 개형은 만성 중증 천 식의 특징 중의 하나이다. 천식의 기도에서 혈관성이 증가되고 기도 점막에 $\mathrm{VGEF}$ 나 $\mathrm{VGEF}$ 의 수용체가 증가 되어 있다. $\mathrm{VEGF}$ 는 혈관투과성을 증가시키고 기도벽의 부종에 기여한다. 또한 천식의 유도객담에 서 $\mathrm{VGEF}$ 가 증가된다. $\mathrm{VEGF}$ 의 발현 세포수는 기도 반응성과 관련이 있으며 $\mathrm{VEGF}$ 의 수용체 억제제는 염증이나 기도과민반응을 억제한다. 폐 특이성 $\mathrm{VEGF}$ 의 발현의 증가는 $\mathrm{Th} 2$ 염증, 근세포의 증식 그 리고 기도 과민반응을 증가시킨다. TGF- $\beta, \mathrm{IL}^{-1} \beta$, 그리고 $\mathrm{PDGF}$ 등의 성장인자나 싸이토카인은 기도 평 활근에서 $\mathrm{VEGF}$ 단백질의 발현을 증가시키고 prostaglandin E2, bradykinin 그리고 Th2-type cytokine 또한 기도 평활근의 $\mathrm{VEGF}$ 발현을 증가시킨 다.

\subsection{0.개형에서 아세틸콜린의 영향}

기도 평활근 세포는 증식하거나 이주할 수 있고 chemokine, cytokine, 세포외 기질 단백질과 성장인 자 같은 물질을 분비할 수 있다. 또한 이것에 반응하 여 수축성에서 증식성/합성 혹은 과수축성으로 표현 형을 바꿀 수 있다. 많은 급성 염증성 매개체 (bradykinin, leukotrienes, histamine )는 기도 평활근 세포막에 있는 G 단백-연계성 수용체(GPCRs)를 통 하여 효과를 나타내는데 아세틸콜린을 포함한 축성 의 신경 전달 물질도 기도 평활근의 GPCRs을 활성화 하기 때문에 아세틸콜린은 기도에서 수축이외의 더 많은 기능을 나타낼 것이다. 기도의 아세틸콜린의 일 차적으로 미주신경에서 나온다. 미주신경으로부터의 아세틸콜린의 유리는 자동억제성의 $\mathrm{M} 2$ 수용체를 포 함하는 여러 가지 접합전(prejunctional) 수용체에 의 해서 조절된다. 알레르기성 기도 염증과 천식의 동물 의 모형에, $\mathrm{M} 2$ 자동수용체의 기능부전으로 미주신경 에서 과장되게 많은 아세틸콜린을 유리한다. 호산구 가 미주신경으로 이동하여 $\mathrm{MBP}$ 를 유리하여 
allosteric M2 수용체 길항제로 작용하여 일부 천식환 자에서 $\mathrm{M} 2$ 수용체 기능부전을 초래한다. 자동 억제 이외에 호산구의 $\mathrm{MBP}$ 는 상피세포를 탈락시키고 감 각성 신경종말을 기도 내강으로 노출시키므로 흡입 성 자극에 대하여 콜린성 반사 활동과 알레르기성 기 도 과민성을 더 강하게 하는 데 기여 할 것이다. 구심 성 감각의 신경 종말은 또한 히스타민, 브래디키닌, 세로토닌, 아데노신과 endothelin 같은 염증성 매개체 에 의한 중심 반사성 기관지 수축을 일으킨다.

기도 염증에서 여러 가지 기전에 의해서 미주신경 의 아세틸콜린 유리가 증가 된다. 아세틸콜린이 증가 가 천식에서도 중요한 역할을 하지만 항콜린성약제 는 미주신경 긴장이 기도 폐쇄의 유일한 가역성 구성 요소인 것처럼 보이는 $\mathrm{COPD}$ 에서 주로 사용된다. 또 한 미주신경이 아세틸콜린의 중요한 공급처이지만 기관지 상피 세포, T와 B 림프구, 비만 세포, 단핵세 포, 과립구, 폐포 대식 세포와 기도 평활근 세포도 아 세틸콜린을 생산하고 또는 그 합성효소인 choline acetyltransferase (ChAT)를 나타낸다. 현재, 염증성 기도 질환의 자가분비 혹은 또는 paracrine 호르몬으 로서의 아세틸콜린의 역할은 아직 확립되지 않았다.

기도 평활근은 $\mathrm{Gi}^{-}$coupled $\mathrm{M} 2$ 와 $\mathrm{Gq}^{-}$coupled $\mathrm{M} 3$ 수용체를 나타내며 전자가 총 무스카린 수용체의 80\%를 차지한다 이 수용체는 주로 MAP kinase와 $\mathrm{PI} 3-k i n a s e$ 신호전달 경로 같은 성장인자에 의해 활 성화되는 것을 비롯하여 다양한 신호전달 경로와 상 호 의사전달(cross-talking)하는 복합적인 세포내의 신호전달 그물망의 일부를 형성한다.

\section{1) 표현형, 수축력과 수축성 단백질의 발현}

기도 평활근은 발육 정지시 혹은 인슐린에 반응하 여 더 신속하고 강력한 수축력과 수축성 수축 조절 단백질(예 smooth muscle- pecific actin, myosin and myosin light chain kinase (MLCK) 의 발현을 증가 시키며 M3가 증가 된다. 반대로, 기도 평활근은 성장 인자 또는 우태아혈청(fetal bovine serum)에 반응하 여 증식하도록 촉진되면 덜 수축적이고 수축성단백 질과 $\mathrm{M} 3$ 수용체의 발현이 감소되는 표현형으로 전환 될 수 있는 데 이것은 $\mathrm{p} 38, \mathrm{p} 42 / \mathrm{p} 44 \mathrm{MAP}$ kinase 그리
고 PI3-kinase에 의존한다. 이와 같이 수축성이 낮은 표현형은 증식성이 증가되고 천식이나 $\mathrm{COPD}$ 에서 볼 수 있는 기도 평활근 덩어리의 증가에 기여한다. 무스 카린 수용체 자극은 수축성에 관련된 RhoA와 Rho 키나아제를 촉진한다. 그러나, 지속적으로 높은 농도 의 메타콜린에 배양된 소의 기도 평활근 절편은 현저 하게 수축성이 감소하고 수축 단백(액틴, 마이오신) 의 발현이 감소되며 이것은 $\mathrm{M} 3$ 수용체에 의존하지만 $\mathrm{PKC}$ 에 무관하고 $\mathrm{p} 42 / \mathrm{p} 44 \mathrm{MAP}$ kinase과 PI3-kinase 에 부분적으로 의존한다. 이 수축성의 감소는 세포내 의 $\mathrm{Ca} 2+$ 의 지속성 상승 때문이다. 기니피그에서 반복 적으로 알레르겐으로 자극하면 기도 평활근의 수축 성과 수축 단백 발현이 증가되고 이것은 알레르겐에 의해서 표현형이 전환된 것으로 해석된다. 천식과 $\mathrm{COPD}$ 에서 항콜린제인 tiotropium으로 수축성과 수 축 단백발현이 감소되며 이 결과는 내인성 아세틸콜 린이 알레르겐에 의해 유발된 기도 개형에 관여 할 수 있다는 것을 암시한다.

\section{2) 기도평활근의 증식}

천식과 $\mathrm{COPD}$ 에서 관찰되는 기도 평활근덩어리의 증가는 platelet-derived growth factor (PDGF), epidermal growth factor (EGF), insulin-like growth factor-1 (IGF-1) 그리고 basic fibroblast growth factor (bFGF)와 같은 펩타이드 성장인자에 의해 일 부분 조절된다. 이 인자들은 호산구와 대식세포 등의 염증 세포나 상피세포, 유출된 혈장과 기도 평활근 자 체에 의해서 유리 되어서 염증에 관여한다. 이 성장인 자는 MAP kinases와 PI3-kinase를 활성화하여 증식 반응을 일으키는데 이들은 무스카린 수용체 작용제 에도 작동하지만 무스카린 수용체 단독 자극으로는 사람의 기관지 평활근 세포 증식에 충분하지 않으며 콜린성 작용제는 증식 반응에 필요한 $\mathrm{p} 42 / \mathrm{p} 44 \mathrm{MAP}$ kinase의 활성화를 지속적으로 유발하지는 못한다. 그러나, 무스카린 수용체 자극은 펩타이드 성장인자 와 상호작용으로 기도 평활근 세포에서 mitogenesis 에 상승적인 유도작용을 할 수 있다

\section{3) 기도 평활근의 이주}


아세틸콜린은 기도 평활근 세포 이주에 잠재적으 로 영향을 끼칠 수 있을 것이다.

\subsection{ADAM33}

$\mathrm{ADAM} 33$ 은 염색체 $20 \mathrm{p} 13$ 에 위치한 독특한 천식 감수성 유전자이다. $\mathrm{ADAM} 33$ 은 기도과민성과는 통 계적 유의성이 높고 혈중 $\mathrm{IgE}$ 나 알레르겐 특이성 $\mathrm{IgE}$ 의 증가와는 통계학적으로 유의성이 낮다. 이점은 이 유전자가 염증 자체보다는 변화된 기도의 기능에 가 깝게 연관되어 있는 것을 의미한다. $\mathrm{ADAM} 33$ 은 최근 에 $\mathrm{Zn}++$ 의존성 metalloprotease(metzincins) $\mathrm{ADAM}$ 유전자 가족군의 한 일원으로 알려졌다. $\mathrm{ADAM} 33$ 은 ADAM12, ADAM13 그리고 ADAM19 subfamily 에 속한다. 모두 단백질 분해능이 있으며 $\mathrm{ADAM} 33$ 은 평 활근, 근섬유모세포, 섬유모세포 등에 선택적으로 발 현되지만 상피세포 $\mathrm{T}$ 세포, 염증성 백혈구에는 발현 되지 않는다. 중엽세포에 $\mathrm{ADAM} 33$ 가 선택적으로 발 현되는 것은 이 유전자의 기능적 이상은 천식의 기도 과민성과 연관된 기도 평활근이나 섬유모세포의 이 상의 배경이 되는 것을 의미한다. $\mathrm{ADAM}$ 단백질은 다양한 기능을 같고 있으며 하나 혹은 여러 가지 기 능의 조절의 이상은 기도 과민반응에 기여할 수 있다.

\section{4. 병리 조직학적인 특징}

\section{1 기도 상피세포의 손상}

상피의 탈락이 천식의 특징인가 혹은 취급중에 생 긴 손상인가는 아직 논란이 있다. 최근에 상피 세포가 조직검사하는 동안 혹은 조직고정과 염색과정에서 인공적으로 손상 받는 것으로 강조되고 여러 연구에 서 천식이 아닌 환자와 차이가 없다고 보고하고 있다. 또한 상피세포의 손상의 정도는 폐 기능의 이상 정도 나 기도 과민반응성과 비례한다고 알려져 왔으나 최 근에는 부정적인 보고도 있다. 기도손상은 질환의 중 증도를 반영하지만 그것 보다는 상피세포의 표현형 의 변화가 아래층에 있는 근육세포의 과반응이나 중 엽세포의 이주, 기질의 침윤을 조장한다는 점이 강조
되고 있다.

\section{2 점막 분비선의 비후와 중식}

치명적인 천식환자에서 술잔세포의 비대, 혹은 증 식이 일관되는 소견이다. 점액분포나 술잔세포의 증 식 정도는 천식의 중증도와 비례하지는 않지만 중등 도의 천식은 경증의 천식에 비하여 점액분비가 많고 사망한 경우에는 술잔세포면적과 점액분비 모두 증 가되어 있다. 기도점액은 기도벽에 침윤된 염증세포 들간의 상호작용과 기도상피와 점막하의 혈관과 분 비 세포의 병적인 변화를 반영하며 질적 양적으로 비 정상적이다. 이변화는 기도점액의 점도, 유동학적인 특징과 점액섬모청소율의 이상을 초래한다. 객담내에 호산구수가 증가하고 호산구의 lysophospholipase로 구성된 bipyramidal 결정체 (Charcot-Leyden crystal)를 볼 수 있고, 천식에서 기도분비에서 점액 의 농도는 증가되어 있으며 종종 천식환자의 객담에 서 코르크 마개 따개 같은 트위스트모양의 건조된 점 액(Curschmann's spiral), 탈락된 상피세포의 덩어리 (Creolar body)를 종종 볼 수 있다. 기관지혈관 투과 성의 증가와 증가된 세포성 염증으로 객담내 알부민 과 $\mathrm{DNA}$ 가 증가한다. 기도의 분비는 천식의 특징인 복합적인 염증을 반영하여 혈장에서 유래된 단백질 과 싸이토카인 그리고 chemokine이 기도 분비에서 증가되어있다. 기도에 비정상적으로 축적된 점액은 기도를 폐쇄 시키고 기침과 객담등 증상을 유발한다.

\section{3 그물판의 비후}

천식환자의 상피 바로 직하방에 아교질 III 그리고 $\mathrm{IV}$, fibronectin, tenascin 침착이 증가된다. 이 구조적 단백질들은 전형적인 기저막 단백질과는 다르며 천 식의 상피하 섬유화는 진정한 기저막의 비후가 아니 라 간질성아교질 층의 침착이다. 이 구조적인 단백질 은 천식환자에서 증가하는 근섬유모세포에서 발생한 다. 천식 환자의 기도에는 혈관의 수가 증가하거나 크 기가 커진다. 혈관의 용적이 증가하면 점막의 부종을 일으키고 기도내경을 좁게 한다. 많은 염증매개체들 
이 혈관 확장을 일으키고 모세혈관후 세정맥의 확장 과 혈장누출, 그리고 기도점막의 부종을 일으킨다. 천 식의 기도 평활근은 비대보다는 증식이 더 우세하며 정상보다 2-3배 증가한다. 또한 기도 연골의 이상 특 히 연골의 퇴행과 연골주위의 섬유화가 일어난다.

\section{4 세포외 기질}

천식의 그물기저막, 기도벽, 편활근층내에 전반적 으로 laminin, tenascin, 콜라겐, fibronectin, proteoglycan등이 침착된다.

\section{5 기도 평활근의 비대와 증식}

기도 평활근 덩어리의 증가는 근섬유수나 크기의 증가에 의하여 염증에 의한 기질의 변화와 함께 기도 의 수축력을 증가 시킨다. 나이가 많을 수록 기도 평 활근 두께가 증가하여 천식의 유병 기간이 기도 평활 근의 두께에 영향을 주는 가장 유력한 요소로 생각된 다.

\section{6 점막의 신생혈관의 증가}

일부에서는 혈관 숫자보다는 크기가 증가하는 것 으로 보고되고 논란이 있지만 점막의 혈관의 수가 증 가하고 혈관수가 천식의 중증도와 비례한다고 한다.

\section{7 호산구성 염증}

천식에서 조직학적인 특징은 활성화된 호산구가 상피나 점막하에 증가한다는 것이다.

\section{5. 기도 개형의 진단과 평가}

생리학적으로 또한 임상적으로 의의 있는 기도개 형의 진단과 평가는 증상점수나 폐기능, 천식의 중등 도에 달려 있다. 최근에 가장 확실한 방법은 기관지 조직검사이지만 침습적인 방법이며 위험하고 소아나 반복적으로 시행하기 어려운 점이 있어서 비침습적 인 방법이 필요하다. 호기내 nitric oxide, 유도성 객담 등은 기도 개형에 대한 간접적인 정보를 제공하며. 기 도 초음파검사 혹은 optical coherence tomography, CT scan, 기도표면의 혈관성 측정 등은 기도 개형의 측정이나 장기간 치료 계획에 대한 간단한 방법으로 서 현재 평가 중이다. 고해상도 단층 촬영상 기도 면 적에 대한 기도벽의 두께비는 그물망두께와 비례하 며 두께가 $\mathrm{FEV}_{1}$ 이나 중증도, 염증과 반드시 비례하 지는 않지만 증상이 나타나기 전부터 두께는 증가한 다고 한다. 또한 항원으로 분절 기도유발검사후 PET scan으로 염증을 감지 할 수 있고, hyperpolarized helium으로 환기와 관류를 측정하면 기도 개형의 생 리학적인 면을 이해 하는데 도움이 될 것이다. 또한 $\mathrm{MRI}$ 는 증상이 없는 경우에도 환기의 가역적인 결손

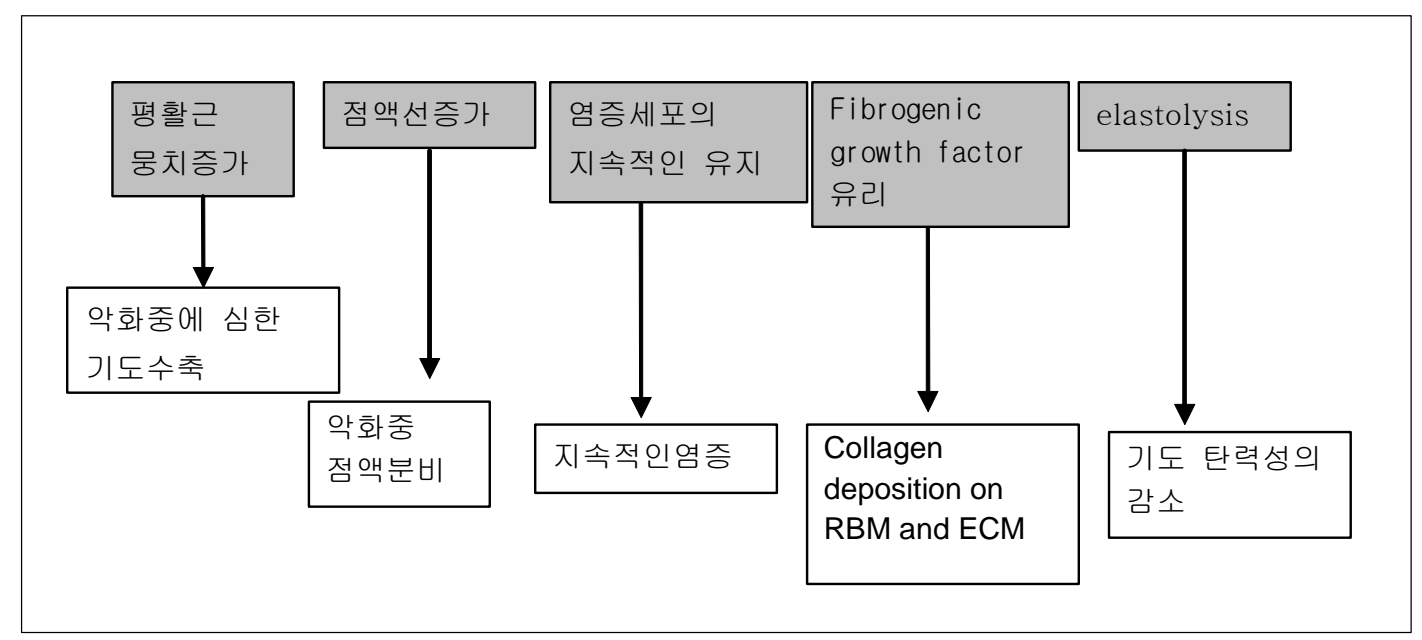


을 찾을 수 있을 것이다. 이 예민한 방법들은 치료에 대한 반응이나 소기도의 이상 정도를 평가하는 데 도 움이 될 것이다. 또한 optical coherence tomography, high speed imaging technology가 조직의 단면도를 측정하는 데 상피나 점막, 연골, 분비선등을 조직과 같이 나타낼 수 있어서 유용할 것이다.

\section{기도 개형의 결과}

기도 개형은 기본적으로 세 가지의 결과를 나타낸 다 첫째; 중등도로 기도벽이 두꺼워지고 안정시에는 별 영향이 없으나 평활근의 단축으로 인한 기도의 수 축에 현저한 영향을 미치고 기도 과민반응에 기여한 다. 둘째; 기도의 비후는 기도 수축의 지속적이고 불 완전한 가역적인 기도의 수축을 초래한다. 셋째; 기도 벽의 증가된 혈관과 술잔세포의 증식과 그리고 점악 하 분비선의 비후는 점액분비를 증폭하고 중증천식 의 악화에 기도를 막는 점액마개를 형성하는 점액의 분비나 혈장단백질의 유출을 증폭한다.

\section{6. 기도 개형과 기능의 연관성}

Moreno등은 기도와 평활근의 기계적인 특성이 변 하지 않는다는 가정하에서 기도 벽 두께의 증가는 기 도 벽 주변의 평활근을 짧게 하기 때문에 기도의 수 축을 증폭시킨다고 하였지만 반대로 기도 개형이 알 레르겐 흡입 또는 과민성반응의 결과로 생기는 과도 한 혹은 너무 자주 발생하는 기도 평활근의 수축과, 폐포의 손상에 의한 기도 지지가 감소되거나, 감작된 평활근세포의 증가된 수축 속도, 비대 혹은 증식으로 생긴 수축력의 증가등에 대한 방어적인 수단일 수도 있다는 보고들이 있다.

Mauad등에 의하면 치명적인 천식에서 특히 기도 의 외곽부분과 바로 주변의 폐실질의 elastin의 손실 이 폐포부착의 손상과 관련이 있으며 이런 변화가 탄 력반동의 감소와 상관관계가 있고 염증에 의해서 단 순히 침착된 산물이 아니라 콜라겐과 다른 단백질이 방어적인 혹은 안정화 시키는 역할을 한다는 점을 제 시하였다. 그래서 기도 개형은 기도를 딱딱하게 하거 나 평활근사이에 일련의 탄력 소를 추가하여 방어적
인 작용을 한다. 그러므로 기도 개형은 기관지 천식의 증가된 불안정을 극복하기 위한 과정일 수도 있다. 고 해상 CT으로 측정한 기도벽의 두께는 기도 과민성과 기도 수축제에 대한 기도 수축반응에 역비례한다. 이 것은 기도 과반응에는 기하학적인 것보다 더 이상의 것이 관여함을 의미한다. 중증 천식에서 지속적인 기 류 폐쇄가 있는 환자는 염증이 더 심하고 기도벽이 더 두껍고, 같은 수준의 치료에도 불구하고 정상 폐 기능 환자보다 이병기간이 더 길다.

\section{7. 기도 개형의 치료}

현재까지 기도 개형의 특이적인 치료제는 알려진 바 없다. 그러나 점점 현재 사용하는 약제의 기도 개 형에 대한 역할이 조금씩 보고되고 있다.

\section{1) 흡입용 스테로이드(ICS)의 효과}

(1) 상피 세포;

기관지폐포세척액내의 상피 세포수를 줄이고 상피 세포의 손상되기 쉬운 상태를 정상화 시킨다. 기관지 중등도와 비례하는 상피세포의 EGF 수용체의 발현 은 ICS에 영향을 받지 않는다. 천식환자에 발현되는 억제된 세포주기의 표식자인 p21(waf) cyclindependent kinase 억제제는 ICS에 의해서 영향을 받 지 않는다. 천식의 상피는 복구이상을 나타내고 불완 전하게 회복하며 ICS에 내성을 나타낸다.

\section{(2) 그물판과 기도 collagen 침윤}

$\mathrm{ICS}$ 치료 후 3 개월에 기관지폐포와 조직검사상 염 증세포가 현저히 감소하지만 12 개월까지 더 추가적 인 효과는 없고 이 항염증효과는 기도 기저막의 두께 의 정상화보다 먼저 나타나고 기관지 과민성에 대한 효과(12개월 후 나타남)보다 먼저 나타난다. 그러나 collagen침윤에 대한 효과는 없다. 기도 염증, 기저막 의 두께, 기도과민 반응성은 서로 상호 관련성이 있지 만 반응은 서로 다른 시간경과를 나타내고, 용량/반 응곡선이 다르다. 그러므로 장기간 또한 일찍부터 ICS를 사용하여야 한다는 것을 의미 한다. 개형에 대 한 ICS의 역할은 단순한 폐기능검사 보다는 주기적 인 기도과민반응이나, 증상점수, 기도 염증을 대변하 
는 객담내 호산구수, 호기성가스내 nitric oxide등으 로 평가할 수 있을 것이다.

\section{(3) 혈관 분포}

흡입용 fluticasone propionate를 저용량(200 $\mathrm{ug} / \mathrm{day})$ 과 고용량(1000 ug/day)을 투여할 때 증상이 나 기도 과민성등은 호전되었으나 혈관수나 기저막 의 두께는 고용량에서만 감소하였다. 그러나 $\mathrm{VEGF}$ 염색이나 기관폐포세척액내 증가된 $\mathrm{VEGF}$ 은 감소하 지 않았다.

\section{(4) 기도 평활근}

평활근을 스테로이드롤 미리 전처치후에 성장인자 에 의한 세포이주를 억제하였고 세포이주에 대한 salmeterol의 억제 기능을 가능하게 하였다. 그러나 생체내에서 세포이주는 주변 기질이나 세포 밀도, cytokine 상태등에 영향을 받기 때문에 연속적인 조 직검사에 의해서 추적해 보아야한다.

\section{2) Anti-IL-5의 효과}

Anti-IL--5는 특히 호산구수를 감소시키고 기관지 점막 그물판에서 tenascin, lumican 그리고 procollagenIII를 현저하게 감소시키고 기도내 TGF- $\beta 1 \mathrm{RNA}$ 를 나타내는 호산구수를 감소시키고 기관폐포세척액 내 $\mathrm{TGF}-\beta 1$ 를 감소시킨다.

3) immunostimulatory $\mathrm{CpG} D N A$ 과 기도 개형 immunostimulatory $\mathrm{CpG} \mathrm{DNA}$ 는 알레르겐으로 반 복적으로 기도를 자극한 경우에 기도 개형을 예방하 거나 반전시키고 예방 모델에서는 기도주위의 평활 근 세포층의 두께, 기도주위의 근섬유모세포의 침윤, 기도주위의 섬유화(peribronchial collagen III and V deposition)를 감소시켰다. 또한 BALF내 혹은 폐조직 내 TGF- $\beta$ 를 감소시켜서 이 기전에 의해서 개형을 억제하는 것으로 생각된다.

\section{4) 류코트라이엔 조절제}

CysLT1 수용체 길항제는 기도 평활근의 증가를 억제하고 LTD4는 성장인자에 의한 평활근의 증식을 증가시킨다. 술잔세포 화생이나 평활근 증식이나 섬 유화를 억제 할 것으로 예상한다.
Collagen 침윤: 술잔세포나 기도 평활근의 증식과 알레르겐 염증반응에 동반되는 섬유화등 개형의 구 조적인 변화를 예방하는데 도움이 된다는 증거가 있 어서 임상적인 조사가 필요하다.

기도 평활근 증식;알레르겐으로 처리한 쥐에서 기 도 평활근의 증가를 류코트리엔길항제가 억제하였다. 쥐의 기도 개형모델에서 Montelukast는 기도 평활근 의 증식을 억제하였다.

Th2 cytokine 분비: Th2 cytokine의 억제는 류코 트리엔 길항제의 점액선의 증식과 과분비를 약하게 한다.

\section{참 고 문 헌}

1. Huber HL, Koessler KK. The pathology of fatal asthma. Arch Intern Med 1922;30:689 - 760.

2. James AL. Relationship between airway wall thickness and airway hyperresponsiveness. In: Stewart AG, editor. Airway wall remodeling in asthma. New York: CRC Press; 1997. p. 1- 28.

3. Jenkins HA, Cool C, Szefler SJ, Covar R, Brugman S, Gelfand EW, et al. Histopathology of severe childhood asthma: a case series. Chest 2003;124:32 - 41.

4. Payne NR, Rogers AV, Adelroth E, Bandi V, Guntupalli KK, Bush A, et al. Early thickening of the reticular basement membrane in children with difficult asthma. Am J Respir Crit Care Med 2003; $167: 78-82$.

5. Moreno RH, Hogg JC, Pare PD. Mechanics of airway narrowing. Am Rev Respir Dis 1986;133:1171 - 80.

6. James AL, Pare PD, Hogg JC. The mechanics of airway narrowing in asthma. Am Rev Respir Dis 1989;139:242 - 6.

7. Davies DE, Wicks J, Powell RM, Puddicombe SM, Holgate ST. Airway remodeling in asthma: new insights. J Allergy Clin Immunol 2003;111:215 - 25.

8. Knight DA, Lane CL, Stick SM. Does aberrant activation of the epithelialmesenchymal trophic unit play a key role in asthma or is it an unimportant sideshow? Curr Opin Pharmacol 2004;4:251 - 6 .

9. Fernandes DJ, Mitchell RW, Lakser O, Dowell M, Stewart AG, Solwy J. Do inflammatory mediators influence the contribution of airway smooth muscle contraction to airway hyperresponsiveness in asthma? J Appl Physiol 2003;95:844 - 53.

10. Beckett PA, Howarth PH. Pharmacotherapy and airway remodelling in asthma? Thorax 2003;58:163 - 74 . 
11. Ricciardolo FL, di Stefano A, van Krieken JH, Sont JK, van Schadewijk A, Rabe KF, et al. Proliferation and inflammation in bronchial epithelium after allergen in atopic asthmatics. Clin Exp Allergy 2003;33:905 - 11.

12. Dosanjh A, Zuraw B. Endothelin-1 (ET-1) decreases human bronchial epithelial cell migration and proliferation: implications for airway remodeling in asthma. J Asthma 2003;40:883 - 6.

13. Kumar RK, Herbert C, Foster PS. Expression of growth factors by airway epithelial cells in a model of chronic asthma: regulation and relationship to subepithelial fibrosis. Clin Exp Allergy 2004;34:567 - 75.

14. Ebina M, Takahashi T, Chiba T, Motomiya M. Cellular hypertrophy and hyperplasia of airway smooth muscles underlying bronchial asthma: a 3-D morphometric study. Am Rev Respir Dis 1993;148:720 6.

15. Woodruff PG, Dolganov GM, Ferrando RE, Donnelly S, Hays SR, Solberg OD, et al. Hyperplasia of smooth muscle in mild to moderate asthma without changes in cell size or gene expression. Am J Respir Crit Care Med 2004;169:1001 - 6.

16. Benayoun L, Druilhe A, Drombet M, Aubier M, Pretolani M. Airway structural alterations selectively associated with severe asthma. Am J Respir Crit Care Med 2003;167:1360 - 8.

17. Johnson PR, Roth M, Tamm M, Hughes M, Ge Q, King G, et al. Airway smooth muscle cell proliferation is increased in asthma. Am J Respir Crit Care Med 2001;164:474 - 7 .

18. Roth M, Johnson PR, Borger P, Bihl MP, Rudiger JJ, King GG, et al. Dysfunctional interaction of $\mathrm{C} / \mathrm{EBPalpha}$ and the glucocorticoid receptor in asthmatic bronchial smoothmuscle cells. N Engl J Med 2004;351:560 - 74.

19. Capra V, Habib A, Accomazzo MR, Ravasi S, Citro S, Levy-Toledano S, et al. Thromboxane prostanoid receptor in human airway smooth muscle cells: a relevant role in proliferation. Eur $\mathrm{J}$ Pharmacol 2003;474:149 - 59 .

20. Zhou L, Li J, Goldsmith AM, Newcomb DC, Giannola DM, Vosk RG, et al. Human bronchial smooth muscle cell lines show a hypertrophic phenotype typical of severe asthma. Am J Respir Crit Care Med 2004;169:703 - 11.

21. Halayko AJ, Kartha S, Stelmack GL, McConville J, Tam J, Camoretti-Mercado B, et al. PI(3)Kinase/ TOR/p70S6K regulates contractile protein accumulation in airway myocyte differentiation. Am J Respir Cell Mol Biol 2004;31:266 - 75.

22. Brewster CE, Howarth PH, Djukanovic R, Wilson J,
Holgate ST, Roche WR. Myofibroblasts and subepithelial fibrosis in bronchial asthma. Am J Respir Cell Mol Biol 1990;3:507 - 11.

23. Batra V, Musani AI, Hastie AT, Khurana S, Carpenter KA, Zangrilli JG, et al. Bronchoalveolar lavage fluid concentrations of transforming growth factor (TGF)-beta1, TGF-beta2, interleukin (IL)-4 and IL-13 after segmental allergen challenge and their effects on alphasmooth alphasmooth muscle actin and collagen III synthesis by primary human lung fibroblasts. Clin Exp Allergy 2004;34:437 - 44.

24. Bergeron C, Page N, Joubert P, Barbeau B, Hamid Q, Chakir J. Regulation of procollagen I (alpha1) by interleukin-4 in human bronchial fibroblasts: a possible role in airway remodeling in asthma. Clin Exp Allergy 2003;33:1389 - 97.

25. Schmidt M, Sun G, Stacey MA, Mori L, Mattoli S. Identification of circulating fibrocytes as precursors of bronchial myofibroblasts in asthma. J Immunol 2003;171:380 - 9 .

26. Nakamura Y, Esnault S, Maeda T, Kelly EA, Malter JS, Jarjour NN. Ets-1 regulates TNF-alpha-induced matrix metalloproteinase-9 and tenascin expression in primary bronchial fibroblasts. J Immunol 2004; 172:1945 - 52.

27. Shute JK, Solic N, Shimizu J, McConnell W, Redington AE, Howarth PH. Epithelial expression and release of FGF-2 from heparan sulphate binding sites in bronchial tissue in asthma. Thorax 2004;59:557 - 62.

29. Johnson PR, Burgess JK, Underwood PA, Au W, Poniris MH, Tamm M, et al. Extracellular matrix proteins modulate asthmatic airway smooth muscle cell proliferation via an autocrine mechanism. J Allergy Clin Immunol 2004;113:690 - 6 .

30. Freyer AM, Billington CK, Penn RB, Hall IP. Extracellular matrix modulates \{beta\}2-adrenergic receptor signalling in human airway smooth muscle cells. Am J Respir Cell Mol Biol 2004;31:440 - 5.

31. Potter-Perigo S, Baker C, Tsoi C, Braun KR, Isenhath S, Altman GM, et al. Regulation of proteoglycan synthesis by leukotriene $\mathrm{d} 4$ and epidermal growth factor in bronchial smooth muscle cells. Am J Respir Cell Mol Biol 2004;30:101 - 8.

32. McParland BE, Macklem PT, Pare PD. Airway wall remodeling: friend or foe? J Appl Physiol 2003;95:426 -34 .

33. Mauad T, Silva LF, Santos MA, Grinberg L, Bernardi FD, Martins MA, et al. Abnormal alveolar attachments with decreased elastic fiber content in distal lung in fatal asthma. Am J Respir Crit Care Med 2004;170:857 - 62 . 
34. Fredberg JJ, Inouye D, Miller B, Nathan M, Jafari S, Raboudi SH, et al. Airway smooth muscle, tidal stretches, and dynamically determined contractile states. Am J Respir Crit Care Med 1997;156:1752 - 9.

35. Gelb AF, Licuanan J, Shinar CM, Zamel N. Unsuspected loss of lung elastic recoil in chronic persistent asthma. Chest 2002;121:715 - 21.

36. Mauroy B, Filoche M, Weibel ER, Sapoval B. An optimal bronchial tree may be dangerous. Nature 2004;427:633 - 6 .

37. Niimi A, Matsumoto H, Takemura M, Ueda T, Chin K, Mishima M. Relationship of airway wall thickness to airway sensitivity and airway reactivity in asthma. Am J Respir Crit Care Med 2003;168:983 - 8.

38. Pare PD. Airway hyperresponsiveness in asthma: geometry is not everything! Am J Respir Crit Care Med 2003;168:913 - 4.

39. Bumbacea D, Campbell D, Nguyen L, Carr D, Barnes PJ, Robinson D, et al. Parameters associated with persistent airflow obstruction in chronic severe asthma. Eur Respir J 2004;24:122 - 8.

40. Deng L, Fairbank NJ, Fabry B, Smith PG, Maksym GN. Localized mechanical stress induces timeependent actin cytoskeletal remodeling and stiffening in cultured airway smooth muscle cells. Am J Physiol Cell Physiol 2004;287:C440 - 8.

41. Bonacci JV, Harris T, Stewart AG. Impact of extracellular matrix and strain on proliferation of bovine airway smooth muscle. Clin Exp Pharmacol Physiol 2003;30:324 - 8.

42. Ludwig MS, Ftouhi-Paquin N, Huang W, Page N, Chakir J, Hamid Q. Mechanical strain enhances proteoglycan message in fibroblasts from asthmatic subjects. Clin Exp Allergy 2004;34:926 - 30.

43. An SS, Fabry B, Mellema M, Bursac P, Gerthoffer WT, Kayyali US, et al. Role of heat shock protein 27 in cytoskeletal remodeling of the airway smooth muscle cell. J Appl Physiol 2004;96:1701 - 13.

44. Blackburn MR, Lee CG, Young HW, Young HW, Zhu Z, Chunn JL, et al. Adenosine mediates IL-13-induced inflammation and remodeling in the lung and interacts in an IL-13-adenosine amplification pathway. J Clin Invest 2003;112:332 - 44.

45. Grunig G. IL-13 and adenosine: partners in a molecular dance? J Clin Invest 2003;112:329 - 31.

46. Flood-Page P, Menzies-Gow A, Phipps S, Ying S, Wangoo A, Ludwig MS, et al. Anti-IL-5 treatment reduces deposition of ECM proteins in the bronchial subepithelial basement membrane of mild atopic asthmatics. J Clin Invest 2003;112:1029 - 36.

47. Foster PS, Webb DC, Yang M, Herbert C, Kumar RK. Dissociation of $\mathrm{T}$ helper type 2 cytokinedependent airway lesions from signal transducer and activator of transcription transcription 6 signalling in experimental chronic asthma. Clin Exp Allergy 2003;33:688 $-95$.

48. Chakir J, Shannon J, Molet S, Fukakusa M, Elias J, Laviolette M, et al. Airway remodeling-associated mediators in moderate to severe asthma: effect of steroids on TGF-beta, IL-11, IL-17, and type I and type III collagen expression. J Allergy Clin Immunol 2003;111:1293 - 8 .

49. Johnson JR, Wiley RE, Fattouh R, Swirski FK, Gajewska BU, Coyle AJ, et al. Continuous exposure to house dust mite elicits chronic airway inflammation and structural remodeling. Am J Respir Crit Care Med 2004;169:378 - 85.

50. Laprise C, Sladek R, Ponton A, Bernier MC, Hudson TJ, Laviolette M. Functional classes of bronchial mucosa genes that are differentially expressed in asthma. BMC Genomics 2004;5:21.

51. Jongepier H, Boezen HM, Dijkstra A, Howard TD, Vonk JM, Koppelman GH, et al. Polymorphisms of the ADAM33 gene are associated with accelerated lung function decline in asthma. Clin Exp Allergy 2004;34:757 - 60 .

52. Mahut B, Delclaux C, Tillie-Leblond I, Gosset P, Delacourt C, Zerah-Lancner F, et al. Both inflammation and remodeling influence nitric oxide output in children with refractory asthma. J Allergy Clin Immunol 2004;113:252 - 6.

53. Cataldo DD, Gueders M, Munaut C, Rocks N, Bartsch $\mathrm{P}$, Foidart JM, et al. Matrix metalloproteinases and tissue inhibitors of matrix metalloproteinases mRNA transcripts in the bronchial secretions of asthmatics. Lab Invest 2004;84:418 - 24.

54. James AL, Maxwell PS, Pearce-Pinto G, Elliot JG, Carroll NG. The relationship of reticular basement membrane thickness to airway wall remodeling in asthma. Am J Respir Crit Care Med 2002;166:1590 5.

55. Shaw TJ, Wakely SL, Peebles CR, Mehta RL, Turner JM, Wilson SJ, et al. Endobronchial ultrasound to assess airway wall thickening: validation in vitro and in vivo. Eur Respir J 2004;23:813 - 7.

56. Armstrong JJ, Leigh MS, Wlaton ID. In vitro size and shape measurement of the human upper airway using endoscopic long-range optical coherence tomography. Opt Express 2003;11:1817 - 26.

57. Niimi A, Matsumoto H, Amitani R, Nakano Y, Sakai $\mathrm{H}$, Takemura M, et al. Effect of short-term treatment with inhaled corticosteroid on airway wall thickening in asthma. Am J Med 2004;116:725 - 31.

58. James A, King G. The computed tomographic scan: a 
new tool to monitor asthma treatment? Am J Med 2004;116:775 - 7 .

59. Tanaka H, Yamada G, Saikai T, Hashimoto M, Tanaka S, Suzuki K, et al. Increased airway vascularity in newly diagnosed asthma using a high-magnification bronchovideoscope. Am J Respir Crit Care Med 2003;168:1495 - 9.

60. Oshita Y, Koga T, Kamimura T, Matsuo K, Rikimaru
$\mathrm{T}$, Aizawa H. Increased circulating $92 \mathrm{kDa}$ matrix metalloproteinase (MMP-9) activity in exacerbations of asthma. Thorax 2003;58:757 - 60 .

61. James A. Airway remodeling in asthma. Curr Opin Pulm Med 2005;11:1 - 6.

62. Fahy JV, Corry DB, Boushey HA. Airway inflammation and remodeling in asthma. Curr Opin Pulm Med 2000;6:15 - 20. 